\title{
Съвременно състояние на проблема за ларингомалацията при деца с конгенитален стридор
}

Кратьк литературен обзор

\author{
Д. Николов, Н. Криворов, И. Йовчев \\ УМБАЛ „Св. Георги“ - Пловдив, Клиника по УНГ-болести
}

Настоящата публикаиия е част от научен проект ДО02.349/29.12.2008 2. „Интегриран научно-изследователски иентър по детско здраве“, осъществяван с финансовата подкрепа на Фонд „Научни изследвания към $\mathrm{MOH}^{\prime \prime}$.
Л арингомалацията е странно заболяване, при което тонусът на ларингеалната мускулатура е слаб и неустойчив, вследствие на което настъпва динамичен пролапс на меките тъкани на супраглотиса към кухината на ендоларинкса, при което при дишане се чува характерен инспираторен стридор. Това е най-често срещаната конгенитална аномалия на ларинкса в ранната детска възраст $(4,5)$.

Терминът ларингомалация за първи път се въвежда от Jackson и Jackson през 1942 година (1). Първото описание на конгенитален ларингеален стридор се среща във френски учебник по педиатрия от 1897 г. от Barthez и Rillet (2). Авторите описват дете с инспираторен стридор, появил се малко след раждането и спонтанно изчезнал на 10-месечна възраст. Те предполагат, че причината за стридора се дължи на компресия на ларинкса от разрастнала тимусна жлеза или на вродена хипертрофия на щитовидната жлеза. Sutherland G.A и Lack H. L са първите, които извършват директна ларингоскопия на 18 деца с вроден ларингеален стридор и описват характерния динамичен колапс на супраглотичните структури по време на инспириум. Те описват и характерната омегаобразна форма на епиглотиса (3).

\section{Честота}

Ларингомалацията е най-често срещаната причина за ларингеален стридор при новородените и е най-честата вродена аномалия. Честотата, според 
различните автори варира от 45\% до $75 \%(4,5)$. За по-висок процент съобщават Pablo Berthrand et all (6), които правят ретроспективен анализ на 324 случая на деца със синдром на Даун, съчетан с различна белодробна патология и стридор. При $24 \%$ от изследваните болни откриват ларингомалация, при 18\% откриват трахеомалация, при 14\% откриват допълнителен трахеален бронх, при 8\% - бронхомалация. Fabio Midula et all (7), изследвайки секрети, взети при бронхоалвеоларен лаваж, доказват, че такива деца почесто боледуват от пневмонии, поради честите епизоди на микроаспирация.

\section{Етиологични теории}

Въпреки че заболяването е описано толкова отдавна, все още причината му е неизяснена. В литературата се предлагат различни теории, които не почиват на убедителни доказателства. Анатомичната теория - предполага абнормно натрупване на епител в супраглотисното пространство, който увеличава обема на ариепиглотичните гънки $(8,9,10)$.

Картилагинозната теория предполага вродена недоразвитост на хрущялния скелет на ларинкca, което води до недоразвитост, по-голяма гъвкавост и пластичност. Серийни хистологични проучвания (11) на деца с ларингомалация, претьрпели хирургическо лечение, обаче не показват патологични промени.

Невро-мускулната теория - напоследък все повече се застьпва тезата за неврологични механизми, които повлияват мускулния тонус на ларинкса и водят до стридор. Невро-мускулната хипотония е най-често цитираната неврологична етиологична причина (12). В последните години прави впечатление високата степен на асоциация между гастроезофагеалния рефлукс и ларингомалацията $(13,14,15,18)$. След въвеждането на електрофизиологичните изследвания на ларинкса днес се смята, че сензорно-моторната интеграция на периферните аферентни рефлекси, малкомозъчната функция и моторният еферентен отговор са отговорни за ларингеалната функция и тонуса на ларингеалната мускулатура. Това е рефлекс, медииран от нервус вагус, познат като ларингеален аддукторен рефлекс (ЛАР), който осигурява аддукцията на глотиса и включва акта на прегльщането.
ЛАР се активира от стимулация на механорецепторите и хеморецепторите, намиращи се в областта на лигавицата на ариепиглотичните гънки. Стимулацията на тези рецептори изпраща сензорна аферентна информация до малкия мозък. Информацията се интегрира от нуклеус трактус солитарии и нуклеус амбигуус. От тук следва неволев еферентен отговор по пьтя на н. вагус. Този импулс резултира в моторен отговор на аддукция на гласните връзки и стимулиране акта на преглъщането. Този еферентна вагусова стимулация е отговорна също така и за тонуса на ларингеалната мускулатура. Увреда или дисфункция някъде по пътя на еферентната и/или аферентната дъга е логично да доведе както до намаляване на ларингеалния тонус, така и до гълтателни смущения, които са вторият по честота симптом след ларингеалния стридор $(15,16,17,18)$. Сензомоторната функция на ларинкса и ларингеалния аддукторен рефлекс днес е възможно да бъдат тествани по време на фиброендоскопско изследване на ларинкса чрез измерване времето за настъпване на аддукция на гласните връзки при пулсово подаване на въздушен поток под определено налягане през катетъра на фиброендоскопа директно върху ариепиглотичните гънки. Измерва се времето, в милисекунди, за настьпване на аддукция и затваряне на глотиса, както и налягането на въздушния поток в милиметри живачен стълб (18). Установени са и средни норми при новородените, които са в порядъка на 50 милисекунди за отговор и налягане на въздуха от 2,5 до 10 милиметра живачен стълб (17).

В клиничната картина на заболяването има някои характерни особености: Различен по степен и интензитет инспираторен стридор, кашлица и задавяне по време на сукане, регургитация. Обструкцията на горния дихателен път води до аерофагия и раздуване на стомаха, вагусова стимулация и постпрандиално повръщане, което де факто довежда до гастроезофагеален рефлукс и увреждане на рецепторните окончания в областта на ариепиглотичните гънки. Същевременно стридорьт се засилва по време на сукане, при плач или при лежане по гръб (20).

Диагностиката на заболяването се извършва с помощта на фиброларингоскопия с детски фиброларинго- или фибробронхоскопи с външен диаметьр 2,2 - 3 мм. Изследването се извърш- 
ва без анестезия или със съвсем лека седация. Това дава възможност за обективизиране на ларингоскопичната картина в динамика и преценяване на степента на инспираторния колапс на супраглотичните структури към кухината на ендоларинкса (18). Ларингоскопичната картина е много характерна.

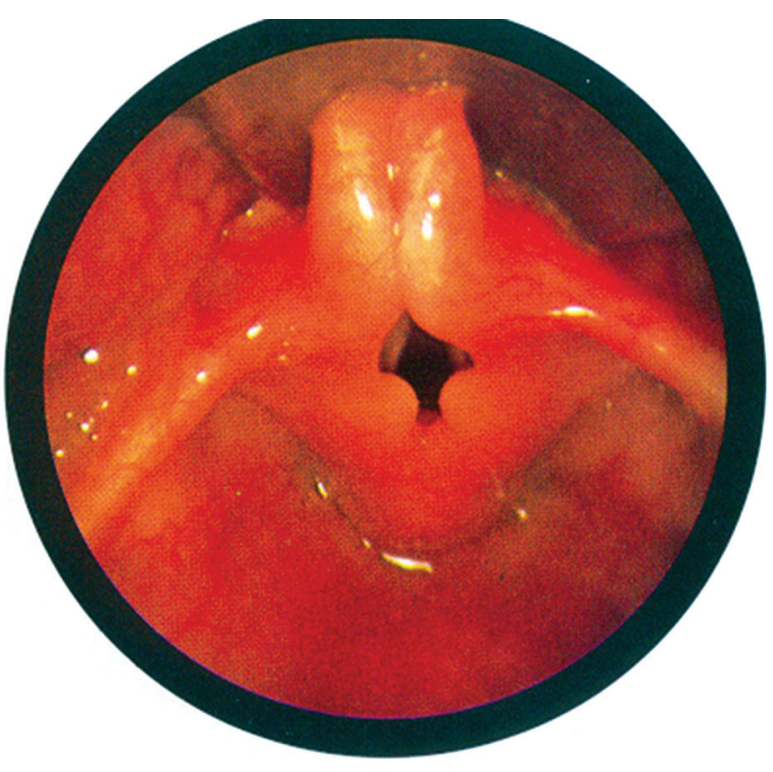

Епиглотисът е елонгиран, понякога има цилиндрична форма или форма на гръцката буква омега. Ариепиглотичните гънки изглеждат скъсени, понякога удебелени, и колабират при инспириум към глотиса. Някои автори разграничават шест различни вида ларингоскопична картина, като измененията могат да се срещат самостоятелно или в комбинация помежду си:

1. Издължен цилиндричен омегаобразен епиглотис;

2. Пролапс при инспириум на кунеиформените хрущяли;

3. Пролапс при инспириум на аритеноидните хрущяли;

4. Епиглотис, който при инспириума пада напред и обтурира входа на глотиса;

5. Къси и задебелени ариепиглотични гънки;

6. Съчетание на някои от тези характерни ларингоскопични находки (24).

Някои автори препорьчват при такива деца освен фиброларингоскопия да се извършва и фибробронхоскопия, с оглед изключване на конгенитални трахеални стенози, трахеомалация или вродени аномалии на трахеобронхиалното дърво (25). По време на фибробронхоскопията задължително се извършва и бронхиален лаваж, при което се отчита нивото на липидите в алве- оларните макрофаги. Тяхното покачване е косвен симптом за микроаспирация на стомашно съдържимо и показва възможността за развитието на белодробни възпалителни процеси.

Според тежестта на клиничната симптоматология заболяването се дели на лека, средно тежка и тежка степен (18). Началото му е около втората - третата седмица след раждането. При леката степен е налице само стридор, който се засилва при лежане по гръб. При средно тежкаma степен са налице затруднения в храненето, регургитация и загуба на тегло. При тежката степен се наблюдава цианоза по време на хранене, поврьщане, кашлица, продължителни апноични паузи, в по-напреднали случаи може да се срещне пектус екскаватус, пулмонална хипертензия кор пулмонале. Апноичните паузи могат да доведат и до внезапна смърт.

\section{Лечение}

Според повечето автори в 90\% от наблюдаваните случаи на деца с лека и средно тежка форма времето е единственият фактор за естествената резолюция на заболяването $(23,24)$. Започвайки между $2^{- \text {-а }}$ и $3^{\text {-та }}$ седмица от раждането, продължава и спонтанно изчезва до $24^{-я}$ месец от живота на детето $(24,27)$. При деца с доказан гастроезофагеален рефлукс и ларингомалация прилагането на антирефлуксна терапия с медикаменти инхибитори на протонната помпа - Omeprasol или $\mathrm{H}_{2}$-блокери, за около 8 - 12 месеца, повлиявайки симптомите на рефлукса, намалява и стридора, и другите смущения по време на хранене $(25,27,29)$. При тежка степен на ларингомалация, придружена с животозастрашаваща диспнея, цианоза, явления на тотален тираж, кор-пулмонале, белодробна хипертония и пектус екскаватус се препоръчва ендоскопска супраглотопластика. Тя се състои в ендоскопско изрязване на колабиращите структури на супраглотиса посредством микроножици или с помощта на $\mathrm{CO}_{2}$-лазер. В редки случаи, при необходимост, предварително се извършва и трахеотомия $(30,31)$. При манифестно изразен омега-образен епиглотис се препоръчва инцизия само на ариепиглотичните гънки. Техниката на супраглотопластиката през последните 20 години се наложи като средство на избор при лечение на тежките случаи на ларингомалация. Компликации от оперативните процедури се наблюдавани при $8 \%$ от случаите (30). Те 
вкЛЮчват:

• постоперативни едеми на тъканите;

• постоперативни грануломи;

• трайни супраглотични стенози се наблюдават в 4\% от лекуваните болни, които са налагали извършването на трахеотомия $(29,30,31)$.

В заключение можем да обобщим, че найправдоподобната причина за възникването на ларингомалацията е нарушението на сензоромоторната интегративна функция на ларинк- ca в резултат на увреждане на аферентната и еферентната рефлексна дъга на ларингеалния аддукторен рефлекс. В около $90 \%$ от случаите настъпва спонтанно излекуване в рамките на около 24 месеца. Диагностиката се извършва основно посредством фиброларингоскопия, без анестезия или с незначителна седация, за да може ларингеалната функция да се оцени в динамика. Тежките форми на заболяването за щастие са изключително редки и се лекуват оперативно.

\section{Литература:}

1. Jackson C., Jackson C.: Diseaeses and injuries of the larynx. New York. Mc Milan. 1942

2. Barthez E, Rilliet F.: Traiate Clinique et pratique des maladies des enfants. Paris. Germer Bailliere, 1843, 484-488

3. Sutherland G. A., Lack H. L.: Congenital Laryngeal obstruction. Lancet 1897; 2: 653-655

4. Ferguson C. F.: Congenital abnormalities of the infant larynx. Otolaryngol. Clin. North A m.1970, 3, 185-200

5. Hollinger P,. H. Johnson K. C., Schiller. F.: Congenital anomalies of the larynx Ann. Otol. rhinol. Laryngol 1954; 63; 581-606

6. Pablo Bertrand, Nils Holmgren, Ignacio Sanches: Airway anomalies in childrens with Downs syndrome endoscipic findings. Pediatrick pulmonology vol 36 Issue2 pp 137-141 Aug 2003

7. Fabio Midula, Robert Guidi, Giancarlo Tancredi, Quatruchi Sergio Botero, Katia Vestiti, Paola Francalanchi, Renato Cutera: Microaspiration in infants with laryngomalacia The Laryngoscope vol 114 Issue 9 pp 1592-1596 Sept 2004

8. Hollinger L. D., Konior R. J.: Surgical management of severe laryngomalacia Laryngoscope 1989; 99, 1136-1142

9. Baxter M. R.: Congenital laryngomalacia. Can. J. Anesth. 1994; 41; 332-339

10. Ferguson C. F.: Congenital abnormalities of the infant larynx Oto Laryngol. clin North Am. 1970; 3; 185-200

11. Lane R.W., Weider D. J., Steinem C, Marin Padila M.: Laryngomalacia A review and case report of surgical tratement with resolution of pectus excavatum Arch Otolaryngol 1984; 110; 546-551

12. Belmont J. R., Grunfast K.: Congenital laryngeal stridor (Laryngomalacia) etiologic factors and asociated disorders Ann Otol Rhinol Laryngol 1984; 93; 430-437

13. Giannony C., Sulek M., Friedman E. M.: Gastroesophageal leflux association wth laryngomalacia a prospective study Int. J. Pediatrr Otorhinolaryngol $1998 ; 43 ; 11-20$

14. Mattheus B. L., Little J. P., Mc Guirt W. F., Koufman J. A.: Reflux in infants with laringomalacia. Results of 24. hour double probe Ph monitoring. Otolaryngol Head and Neck Surg 1999; 120; 860-864

15. Apley J.: The infant with stridor a follow up survey at 80 cases. Arh.Dis. Child 1953, 28; 423-425

16. Lucier G. E., Storey At., Sessle Bg.: Effects of upper respiratory tract stimulion neonatal respiration: reflex and single neuronanalyses in kitten Biol .Neonate 1979: $35: 82-89$

17. Lee J. C., Stoll B. J., Downing S. E.: Propperties of the laryngeal chemoreflex in neonatal piglets. AM J Physiol 1977 ; 233 R $30-R 36$

18. Dana Mara Thompson: Abnormal sensorymotor integrative function of the larynx: A new theory of the etiology The Laryngoscope Vol 117 pp 1-33 June 2007

19. Zeitouni A., Manoukian J.: Epiglotoplasty in the treatment of laryngomalacia J Otolaryngolagy 1993; 22 pp 29-33

20. Rudolph C. D., Mazur L. J., Liptak G. S.: Guidelines for evaluation and tratement of gastroesophageal reflux in infants and children J. Pediatr. Gastroenterlogy.Nutr 2001; 32 S1-S31

21. Lees D.: Larynx from an infant a pecicullar form of obstructed respiration. Trans Pathol Soc Lond 1883: $34: 19$

22. Schwartc L.: Congenital laryngeal stridor (inspiratory laryngeal collapse)A new theory as to its underlying cause and the didsirability of a change in therminology. Arh Otolaryngol. 1944; 39; 403-412

23. Mc Swiney P. F., Cavanagh N. P., Languth P.: Outcome in congenital stridor (Laryngomalacia) Arch Dis Child 1977 52; $215-218$

24. Greinwald J. H., Smith R. J. H., Bauman N. M.: Laryngomalacia and its treatment Laryngoscope 1999; 109; 1770-1775

25. Hollinger L. D.: Congenital webs, cysts, laryngocelles and other anomalies of the larynx Ann Otol Rhinol Laryngol 1967; 76; 744-752

26. Friedman E. M., Vastola A. P., Mc Gill T. J., Healy G.B.: Chroinic Pediatric stridor and outcome Laryngoscope 1990; 100; 277-280

27. Giannoni C., Sulek M., Friedmen E. M.: Gastroesophageal reflux associacion with Laryngomalacia a prospective study .Int J Pediatr Otorhinolaryngol 1998; 43; 11-20;

28. Polonovski J. M., Contencin P., Francois M.: Treatment of severe Laryngomlacia Ann Otol Rhinol Laryngol 1990; 99 ; 625-627

29. Prescot C. A.: The current status of corrective surgery for laringomalacia Am J Otolaryngol 1991; 12; 230-235

30. Denoyelle F., Mondain M., Gressilon N.: Failures and complication of supraglottoplasty in children Arch Otolaryngol Head Neck Surg 2003; $129 ; 177-1080$

31. Reddy D. K., Matt B. H.: Unilateral Versus bilateral supraglottoplasty for severe laringomalacia in children Arch Otolaryngol Head Neck Surg 2001; 127; 694-699

32. Fabiana Cardoso, Pereira Valera, Edwin Tamashiro, Heidi H. Sander: Arch Otolaryngol Head Neck Surg 132 'May 2006 489-493. Evaluation of the efficacy of supraflotoplasty in obstructive sleep apnoe syndrome associated with severe laryngomalacia 